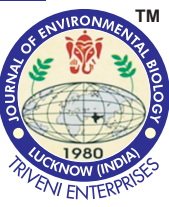

\title{
Colonization of Serratia fonticola on phylloplane of tomato and its impact on leaf cytoplasmic protein profile
}

\begin{tabular}{lll}
\hline Paper received: 03.08.2018 Revised received: 22.11.2018 Re-revised received: 18.02 .2019 & Accepted: 09.03 .2019
\end{tabular}

\begin{abstract}
Authors Info
N. Bhadauria', Shilpi', P.D. Sharma ${ }^{2}$ and P.K. Paul ${ }^{*}$

${ }^{1}$ Cell and Molecular Biology Lab, Amity Institute of Biotechnology, Amity University, Noida-201 313, India ${ }^{2}$ Department of Microbiology, CCS University, Meerut-250 001, India

*Corresponding Author Email : prabir_kp@rediffmail.com
\end{abstract}

\section{Edited by \\ Dr. A. Hemantranjan}

Reviewed by

Dr. Jai Prakash

Dr. Sumati Gaumat

\section{Abstract}

Aim : The aim of the present study was to understand the impact of human enteric pathogen (Serratia fonticola) colonization on cytoplasmic protein profile of tomato leaves.

Methodology : Aseptically grown plants were inoculated with S. fonticola and sampled at different interval of time. Colonization pattern was studied by leaf impression technique. Changes in cytoplasmic protein profile were studied by protein-protein crosslinking method followed by separation through SDS PAGE.

Results : The colonization pattern study revealed that maximum colonies were found at $24 \mathrm{hr}$ post inoculation which gradually decreased with time, showing the survival of the pathogen on phylloplane. Electrophoretic separation of cytoplasmic proteins showed crosslinking of some proteins in treated samples at 48,72 and $96 \mathrm{hr}$ postinoculation.

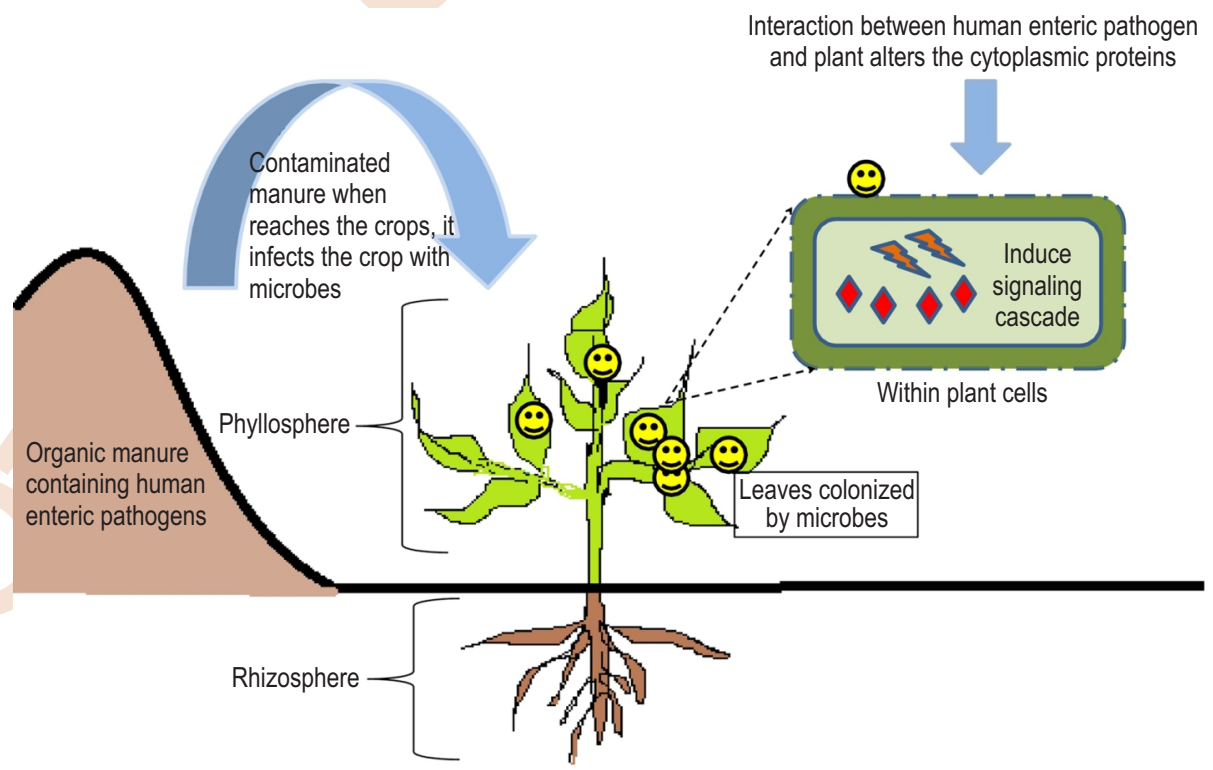

Interpretation : This study will help in understanding the molecular changes in cytoplasmic protein profile and survival of pathogen on phylloplane, thus limiting the growth of bacteria, Serratia fonticola on phyllosphere.

Key words: Cytoplasmic proteins, Human enteric pathogen, Phyllosphere, Serratia fonticola

How to cite : Bhadauria, N., Shilpi, P.D. Sharma and P.K. Paul: Colonization of Serratia fonticola on phylloplane of tomato and its impact on leaf cytoplasmic protein profile. J. Environ. Biol., 40,607-612 (2019). 


\section{Introduction}

Contamination of fresh farm produce with enteric pathogens is today a global concern. Numerous outbreaks associated with the consumption of contaminated lettuce, spinach, tomatoes, berries, and various types of sprouts have been reported in the United States, Canada, Asia and Europe (Hedberg et al., 1999; Beuchat 2002; CDC 2006; Martínez-Vaz et al., 2014). Pathogens beside colonizing human gut are also able to colonize plant parts. The pathogens for these outbreaks were reported to be Salmonella enterica, E. coli 0157:H7, Campylobacter, Yersinia spp. etc. (Heaton and Jones, 2008; Brandl, 2006). Human diseases caused due to colonization of preharvest crops by $S$. enterica has been reported more in postharvested crops. Bacterial species naturally colonizing plants tend to protect invading human bacterial species from desiccation which ensure their survival on leaf surface (Poza-Carrion et al., 2013).

The main source of human enteric pathogens on fresh farm produce is due to irrigation with sewage treated water and application of animal dung as manures. In a recent study, the presence of Klebsiella pneumoniae, Serratia fonticola, Enterobacter ludwigii, Stenotrophomonas maltophilia, Chryseobacterium jejuense were reported to colonize fruits and leaves of Solanum lycopersicum and roots of Raphanus sativus (Gaur et al., 2016). Interaction of human enteric pathogen ( $K$. pneumoniae) with $P$. syringae pv. tomato has been reported to reduce the ability of colonization of $P$. syringae pv. tomato on plants (Gaur et al., 2017). Information on the molecular interaction of these microbes with plant tissue is meagre however, such studies are important for understanding the adaptation of these microbes to survive. Human enteric pathogens can survive on plant surface along with resident microbes and are able to establish cell to cell communication. This behavior amongst the bacteria is density dependent and named as "Quorum sensing" (Schuster et al., 2013). Previous studies on colonization of Salmonella enterica and E. coli 0157:H7 on tomatoes and lettuce have revealed that these pathogens induce expression of genes, important for biofilm production, modification of cell surface structures, virulence and for binding onto the leaf surfaces (Carey et al., 2009; Martínez-Vaz et al., 2014). These cellular structures are used by pathogens to colonize plant surface. Surface polysaccharides like colanic acid and LPS produced by E. coli 0157:H7 differentially induce plant defense response, thus affecting the survival of human pathogen on plants, including leafy vegetables like Arabidopsis thaliana and romaine lettuce as a model plant (Jang and Matthews, 2018).

Serratia fonticola has been reported to colonize plant surfaces without causing any damage to plant (Vleesschauwer and Hofte, 2007). Serratia fonticola, isolated in 1979, is an opportunistic human pathogen reported to cause diarrhea in immuno-compromised patients, skin and soft tissue infections followed by trauma (Gavini et al., 1979; Muller et al., 1986; Aljorayid et al., 2016). It is resistant to Penicillin-G, Cephalotoxin and Colistin class of antibiotics. It has been reported that the human enteric pathogens can survive in seeds for long time (Vander Linden et al., 2013). Interaction of resident microbes of the plant with a human enteric pathogen is known but their mechanism of survival on the leaf is not much studied. Seeds, seedlings and subsequently fruits infected with pathogens can be a potent cause of enteric disorders. The molecular mechanism on survival of human enteric pathogen on tomato leaf has not been much studied. Therefore, the objective of the present study was to understand the colonization pattern of Serratia fonticola on phylloplane of tomato and its impact on the profile of cytoplasmic proteins.

\section{Materials and Methods}

Plant material: Seeds of Solanum lycopersicum (Tomato, Var. Pusa Ruby) were procured from National Seed Corporation, New Delhi, India. Seeds were surface sterilized with $0.1 \%$ sodium hypochlorite solution. Sterilized seeds were washed three times with sterilized distilled water to remove traces of hypochlorite. Seeds were sown in sterilized soilrite in plastic trays $(35 \mathrm{~cm} \times 25 \mathrm{~cm} x 6 \mathrm{~cm} ; \mathrm{LxWxH})$. Plants were grown at $25 \pm 1^{\circ} \mathrm{C}$ and $70 \%$ relative humidity with $12 \mathrm{hr}(\mathrm{L} / \mathrm{D})$ photoperiod in the culture room under aseptic conditions. Plants were watered daily with sterile distilled water and weekly with sterilized $100 \%$ Hoagland's solution.

Preparation of inoculum: Sterilized nutrient broth $(50 \mathrm{ml})$ was inoculated with $1 \mathrm{ml}$ of Serratia fonticola stock preserved in glycerol $-20^{\circ} \mathrm{C}$ and incubated overnight at $37 \pm 1^{\circ} \mathrm{C}$ in an orbital shaker incubator. The inoculum was prepared from this overnight stock of Serratia fonticola by adjusting their concentration to $10^{8}$ cells $\mathrm{ml}^{-1}$ (optical density of 0.1 at $600 \mathrm{~nm}$ ) and was used to treat the plants.

Treatment of plants and sampling: Eight-week-old tomato plants were divided into 2 groups, 1 and 2. Each group had 3 replicates. Each replicates had 25 plants. Plants of group 1 (experimental) were inoculated with bacterial culture of Serratia fonticola. The plants of group 2 were sprayed with sterile distilled water and served as control. Plants were sprayed only once on day $1(0 \mathrm{hr})$. The $3^{\text {rd }}$ node leaf from each replicates of treated and control groups were sampled at $0 \mathrm{hr}$ (day 1), $24 \mathrm{hr}$ (day 2), $48 \mathrm{hr}$ (day 3), $72 \mathrm{hr}$ (day 4) and $96 \mathrm{hr}$ (day 5) respectively.

Study of colonization pattern: Five leaf samples were collected from each sampling group. Nutrient agar media was prepared and sterilized. Media was poured in sterile petriplates as $20 \mathrm{ml}$ portions. Leaf impression was taken by pressing the abaxial and adaxial surfaces of leaves separately in petriplates containing media with a glass spreader. This was to ensure there was a contact between the phylloplane and media. The plates were incubated at $37 \pm 1^{\circ} \mathrm{C}$ for overnight in a $\mathrm{BOD}$ incubator. The colonization pattern from each sample was studied by techniques described by Aneja (2003). The same method was repeated for all the samples.

In-vivo crosslinking of cytoplasmic proteins: For in-vivo crosslinking, the control and $S$. fonticola inoculated leaves were 
divided into two groups. One group from each was treated with formaldehyde (crosslinker) and the other was treated with distilled water (control). The samples were named as follows: (a) Control plant leaves (Non-crosslinked), (b) Control plant leaves (Crosslinked), (c) Treated plant leaves (Non-crosslinked) and (d) $S$. fonticola inoculated plant leaves (Crosslinked). One gram leaf sample for each sampling interval $(0,24,48,72,96 \mathrm{hpi})$ were collected and washed twice with sterile distilled water. In-vivo crosslinking of cytoplasmic proteins was carried out following the method of Bhuvaneshwari et al. (2015).

The leaves were cut into small pieces, followed by the addition of $10 \mathrm{ml}$ of $1 \mathrm{X}$ PBS and infiltrated for 10-20 min in a vacuum desiccator. Freshly prepared formaldehyde (18.5\%) was added to bring the final concentration to $1 \%$. The leaf pieces were submerged followed by capping and poking with a needle and placed in vacuum desiccator for $10 \mathrm{~min}$. After $10 \mathrm{~min}$, the vacuum was released slowly. The submerged leaves appeared translucent. A $0.65 \mathrm{ml}$ of $2 \mathrm{M}$ glycine (final concentration 0.125 M) was added to reverse the process of cross-linking and kept in vacuum again for $5 \mathrm{~min}$. On completion of time, the vacuum was released and air bubbles were removed. The infiltrated leaves were rinsed three times with ice-cold $1 \mathrm{X}$ PBS, dried and stored at $-80^{\circ} \mathrm{C}$ for further use.

Extraction of cytoplasmic proteins: Cytoplasmic proteins from replicates of each sample (a-d) was extracted (Opentwetware). One gram of leaf sample was homogenized in cytoplasmic extraction buffer containing $10 \mathrm{mM}$ Tris $\mathrm{HCl}$ buffer ( $\mathrm{pH}$ 8.0), $0.4 \mathrm{M}$ sucrose, $40 \mathrm{mM} \mathrm{KCl}, 2 \mathrm{mM} \mathrm{MgCl}, 1 \mathrm{mM} \mathrm{NaPPi}, 1 \mu \mathrm{g} \mathrm{ml}{ }^{-1}$ Leupeptin, $1 \mathrm{mM} \mathrm{NaVO}_{4}, 1 \mathrm{mM} \mathrm{NaF}, 1 \%$ (w/v) PVP, $5 \mathrm{mM}$ 2mercaptoethanol, $1 \mathrm{mM} \mathrm{PMSF}$ at $4^{\circ} \mathrm{C}, 10 \%$ glycerol and $10 \mathrm{mM}$ DTT. PVP, PMSF and DTT were added just prior to use. The extract was centrifuged at $10,000 \times \mathrm{g}$ for $20 \mathrm{~min}$ at $4^{\circ} \mathrm{C}$. The pellet containing cellular debris was discarded and the supernatant was collected and centrifuged again at $100,000 \times \mathrm{g}$ for $1 \mathrm{hr}$ at $4^{\circ} \mathrm{C}$. The supernatant so obtained was concentrated by addition of acetone (4:6) and incubated at $4^{\circ} \mathrm{C}$ for overnight. The precipitate obtained was centrifuged at $15,000 \times \mathrm{g}$ for $40 \mathrm{~min}$ at $4^{\circ} \mathrm{C}$. The protein pellet thus obtained was dissolved in $10 \mathrm{mM}$ Tris $\mathrm{HCl}$ buffer $(\mathrm{pH}$ 6.8). The protein concentration was quantified by Bradford's assay (Bradford, 1976) and isocratically separated using sodium dodecyl sulfate polyacrylamide gel electrophoresis (SDS-PAGE) followed by coomassie brilliant blue (CBB) staining (Laemmli, 1970).

Statistical analyses: Statistical test was carried out by GraphPad software. Significance was analyzed using t- test. Two tailed $P$ values were calculated at $95 \%$ level of confidence. Mean value of each sampling interval was calculated followed by standard deviation (SD) and standard error of mean (SEM).

\section{Results and Discussion}

The colonization studies revealed that at $0 \mathrm{hr}$ post inoculation (hpi), the leaf surface had a large number of bacterial colonies. Seventeen proteins were separated electrophoretically from $0 \mathrm{hr}$ samples. The control and $\mathrm{S}$. fonticola inoculated samples at $24 \mathrm{hpi}$, showed no changes in protein profile but the numbers of colonies in $S$. fonticola treated leaves were found to be maximum ( $91 \mathrm{CFU}$ per $\mathrm{cm}^{2}, \mathrm{p} \leq 0.0001$, Fig. 1a). After $48 \mathrm{hr}$, the colony count was $87.2 \mathrm{CFU}$ per $\mathrm{cm}^{2}(p \leq 0.0001)$ and a protein of $\sim 11 \mathrm{kDa}$ was prominently observed in the crosslinked sample (Fig. 1b; Fig. 2). The colonization on leaves was significantly higher near the midrib region, near margins and veins.

The number of CFU decreased significantly to 63 ( $p \leq$ 0.0001 ) and $46 \mathrm{CFU}$ per $\mathrm{cm}^{2}$ at 72 and $96 \mathrm{hr}$, respectively (Fig. 1b). The two tailed $P$ value was 0.0066 and results were found to be statistically significant at $95 \%$ level of confidence $(t=6.7473$ and $\mathrm{df}=3$ ). Table 1 shows the mean and SEM value of each sampling interval. The crosslinked samples had $\sim 92 \mathrm{kDa}$ protein. Proteins of $\sim 48$ and $\sim 49 \mathrm{kDa}$ possibly crosslinked at $96 \mathrm{hrs}$ and appeared as a single protein of $\sim 51 \mathrm{kDa}$. The colonization study suggests that there exists an interaction of human enteric
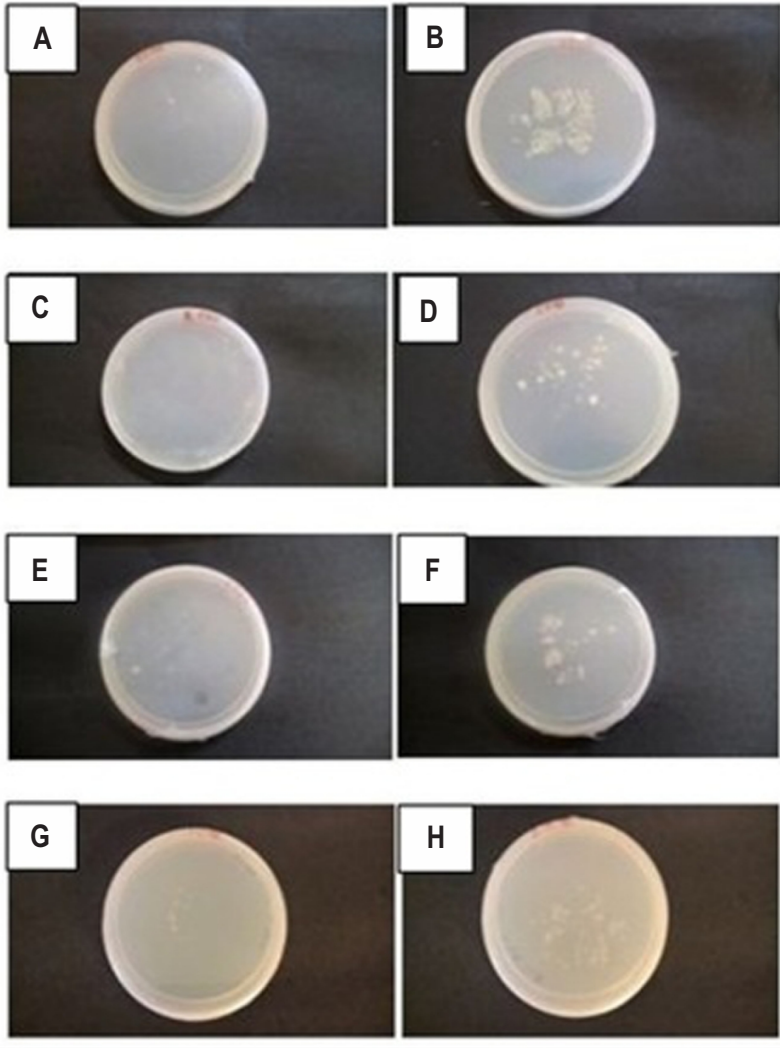

Fig. 1a: Colonization of human enteric pathogens on the phylloplane of leaves. A, B = Leaf Impression at $24 \mathrm{hr}$ post inoculation (Control and $S$. fonticola inoculated); $\mathrm{C}, \mathrm{D}=$ Leaf Impression at $48 \mathrm{hr}$ post inoculation (Control and S. fonticola inoculated); $\mathrm{E}, \mathrm{F}=$ Leaf Impression at $72 \mathrm{hr}$ post inoculation (Control and S. fonticola inoculated) and G, H = Leaf Impression at $96 \mathrm{hr}$ post inoculation (Control and S. fonticola inoculated). 


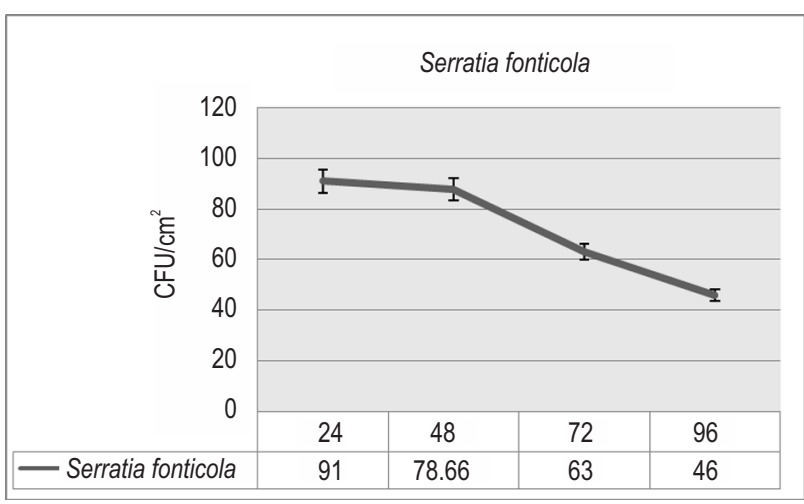

Fig. 1b: Colonization pattern of Serratia fonticola on tomato phylloplane. Vertical bars represent standard error.

pathogens with the leaf surface. HEP tends to make an entry and fit onto the surface, despite not being a resident of phylloplane of tomato. Tomato plants irrigated with contaminated water were found to be more infected with Salmonella enterica as compared to plants grown from seeds in pre-infested soil (Barak et al., 2011).

Several other bacteria from the enterobacteriacae family have previously been isolated from fruits and vegetables (Sahilah et al., 2010; Tunnug et al., 2011; Whipps et al., 2008). Beattie and
Lindow (1999) demonstrated that there are different ways of colonization of bacteria onto the leaf surface. HEPs interact with the local environment and resident bacteria of phylloplane through signal molecules. Environmental factors favor attachment of HEPs on to the leaf surface (Lindow and Brandl, 2003). Human enteric pathogen like Salmonella sp. has ability to internalize within cell after attachment on the plant surface (Golberg et al., 2011). In the studies reported so far, the cellular structures of bacteria like curli, fimbriae or flagella play a major role in colonization. This plant-microbe interaction facilitates the plants for acquiring nutrients, disease resistance and tolerating stresses (Jalil and Ansari, 2018). Metabolic activities in the plants have been reported to influence the capability of enteric bacteria to colonize the leafy greens (Klerks et al., 2007; Quilliam et al., 2012). The gene expression studies in E. coliand Salmonella enterica on lettuce and basil leaves showed the expression of genes to produce curli and flagella (Lim et al., 2014).

In the present study, the colonization results suggested that maximum growth were observed at 24 hpi after which the population stabilized with time which is supported with the modification in cytoplasmic proteins profile. Certain proteins were found to be expressed at 48,72 and 96 hpi which possibly arises due to in vivo crosslinking amongst proteins. At $48 \mathrm{hpi}$, a 11 kDa (kilodalton) protein was observed which may be due to the crosslinking of $\sim 11$ and $\sim 10 \mathrm{kDa}$ proteins. In pathogen treated

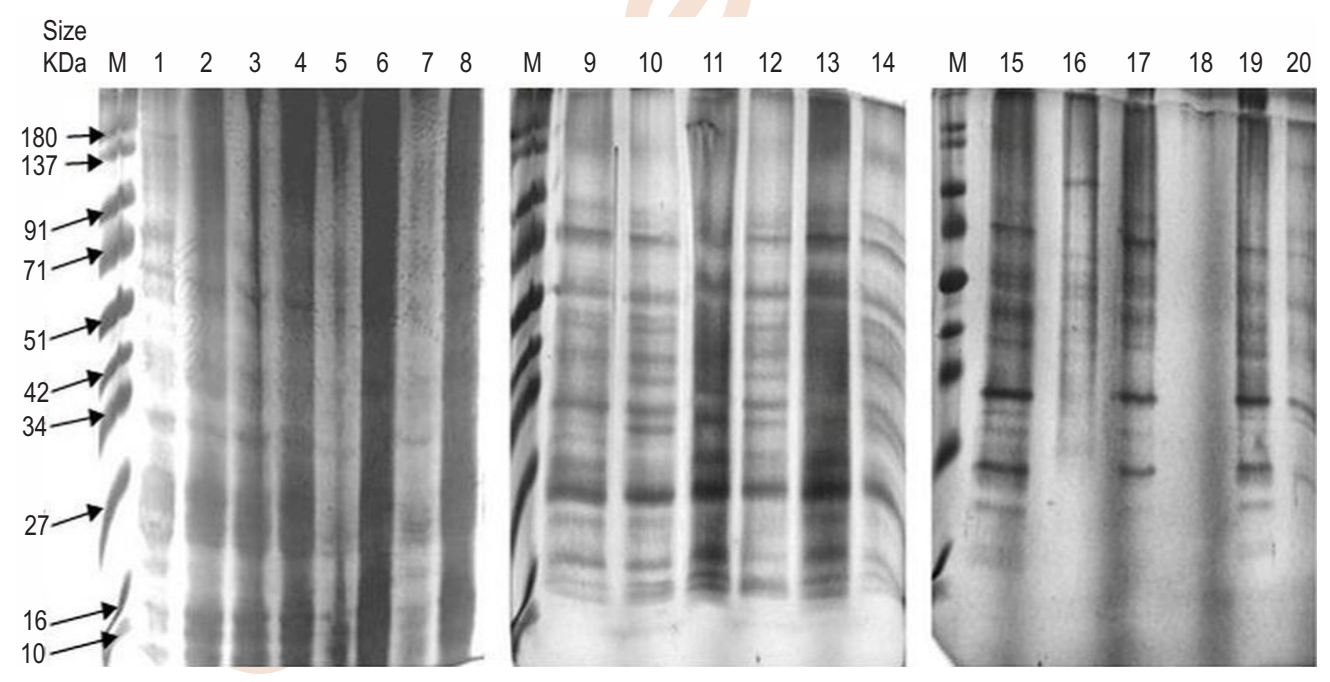

Fig. 2: Cytoplasmic protein profile of leaves treated with Serratia fonticola at different time intervals.

$\mathrm{M}=$ marker; lane $1=$ control leaves at $0 \mathrm{hpi} \mathrm{crosslinked;} \mathrm{lane} \mathrm{2=} \mathrm{control} \mathrm{leaves} 0 \mathrm{hpi} \mathrm{non-crosslinked;} \mathrm{lane} 3=$ leaves inoculated with $\mathrm{S}$. fonticola at $0 \mathrm{hpi}$ crosslinked; lane 4= leaves inoculated with $S$. fonticola at $0 \mathrm{hpi} \mathrm{non-crosslinked;} \mathrm{lane} 5=$ control leaves at $24 \mathrm{hpi}$ crosslinked; lane $6=$ control leaves $24 \mathrm{hpi}$ non-crosslinked; lane $7=$ leaves inoculated with $S$. fonticola at $24 \mathrm{hpi}$ crosslinked; lane $8=$ leaves inoculated with $S$. fonticola at $24 \mathrm{hpi} \mathrm{non-crosslinked;}$ lane $9=$ control leaves at $48 \mathrm{hpi}$ crosslinked; lane $10=$ control leaves at $48 \mathrm{hpi} \mathrm{non}$ - crosslinked; lane 11=leaves inoculated with $S$. fonticola at $48 \mathrm{hpi}$ crosslinked; lane 12= leaves inoculated with $S$. fonticola at $48 \mathrm{hpi} \mathrm{non-crosslinked;} \mathrm{lane} \mathrm{13=} \mathrm{control} \mathrm{leaves} \mathrm{at} 72 \mathrm{hpi}$ crosslinked; lane 14= control leaves $72 \mathrm{hpi}$ non-crosslinked; lane 15= leaves inoculated with S. fonticola at $72 \mathrm{hpi}$ crosslinked; lane 16=leaves inoculated with S. fonticola at $72 \mathrm{hpi} \mathrm{non-}$ crosslinked; lane 17= control leaves at 96 hpi crosslinked; lane 18= control leaves 96 hpi non-crosslinked; lane 19= leaves inoculated with S. fonticola at $96 \mathrm{hpi}$ crosslinked; lane $20=$ leaves inoculated with S. fonticola at 96 hpi non-crosslinked. 
Table 1: Statistical parameters of Serratia fonticola count taken in replicates

\begin{tabular}{lllllll}
\hline Time interval & Replicate 1 & Replicate 2 & Replicate 3 & Mean & SD & SEM \\
\hline $24 \mathrm{hr}$ & 91 & 93 & 89 & 91 & 2.00 & 1.15 \\
$48 \mathrm{hr}$ & 87 & 87.66 & 88.32 & 87.66 & 0.66 & 0.38 \\
$72 \mathrm{hr}$ & 62 & 65 & 62 & 63 & 1.73 & 1.00 \\
$96 \mathrm{hr}$ & 43 & 49 & 46 & 46 & 3.00 & 1.73 \\
\hline
\end{tabular}

sample at $72 \mathrm{hrs}$ interval, there was a significant change in crosslinked samples wherein a $\sim 92 \mathrm{kDa}$ protein was present. Proteins of $\sim 48$ and $\sim 49 \mathrm{kDa}$ possibly crosslinked at $96 \mathrm{hr}$ and appeared as a single protein of $\sim 51 \mathrm{kDa}$.

Proteomic analysis helps in the identification of differently expressed proteins in bacterial colonization (Knief et al., 2011). The maximum growth in bacterial population was at $24 \mathrm{hpi}$ with $\mathrm{S}$. fonticola after which the internalization of bacteria or bacterial metabolites occurs. Erikson et al. (2012) reported that E. coli 0157:H7 internalizes through spinach leaves. These metabolites are responsible for modulations in cytoplasmic proteins. The changes in protein profile was observed after $48 \mathrm{hrs}$ and sustained till 96 hrs which supports the survival of HEPs on phylloplane. Alteration in the protein expression of control and pathogen treated leaf samples show that the enteric pathogen alters the physiology of plant, and are involved in foodborne outbreaks. In S. fonticola inoculated leaf samples, expression of different proteins were observed at different time intervals, which may be due to overexpression of certain specific gene.

The differential expressions of protein in control and $S$. fonticola inoculated samples demonstrate the effect of $S$. fonticola in inducing or suppressing specific genes. However, detailed proteomic analysis reveal the functional aspect of these proteins. These differential gene expressions are sometimes involved in biofilm modulations and are linked with the colonization potential of HEPs which has been reported to reduce the effectiveness of sanitation of fresh produce post-harvesting (Niemira et al., 2010). Since $S$. fonticola does not cause disease in the plants, therefore the plant is able to defend itself by expressing some defense response enzymes (Melotto et al., 2014). These changes help the HEPs to survive on the leaf surface and cope up with the nutrient scarcity and other harsh environmental conditions (Martinez et al., 2014). The cytoplasmic protein expressions in crosslinked inoculated leaf samples suggest that possible internalization of Serratia fonticola modulates gene expression in plants.

This could be due to Pathogen Associated Molecular Patterns (PAMP) in the host plant (Zhang et al., 2014). PAMPs are conserved molecules responsible for the survival of pathogens on the plant surface. So, the study of protein profile helps in understanding the plant-pathogen interactions from a systems perspective. The difference in protein profile supports the fact that HEP can invade plant cells and trigger signaling cascade of the host plant (Schikora et al., 2008). Thus, the interaction of human enteric pathogens on leaf surface possibly follows internalization of pathogen and modulation of cytoplasmic proteins. Quenching of this phenomenon can possibly limit the contamination of fresh produce with human enteric pathogens, thereby limiting foodborne disorders. Serratia fonticola, a human enteric pathogen colonizes on the phylloplane of tomato. This colonization is, however, not latent. It is evident from colonization and protein profile that the pathogen effectively interacts with the phylloplane. S. fonticola effectively induces expression of specific proteins in the cytoplasm of inoculated leaves. The data supports the fact that survival of HEPs is related with the expression of proteins, thus limiting their expression may limit the population of HEPs.

\section{Acknowledgment}

The authors thank Amity Institute of Biotechnology, Amity University Uttar Pradesh, India for providing necessary infrastructure and facilities to carry out the research work.

\section{References}

Aljorayid, A., R. Viau, L. Castellino and R.L. Jump: Serratia fonticola, pathogen or bystander? A case series and review of the literature. IDCases, 5, 6-8 (2016)

Aneja, K.R.: Isolation of microorganisms from phyllosphere (phylloplane): Experiment in Microbiology, Plant Pathology and Biotechnology. NewAge International Publisher, pp. 176-178 (2003).

Barak, J.D., L.C. Kramer and L.Y. Hao: Colonization of tomato plants by Salmonella enterica is cultivar dependent, and type 1 trichomes are preferred colonization sites. Appl. Environ. Microbiol., 77, 498-504 (2011).

Beattie, G.A. and S.E. Lindow: Bacterial colonization of leaves: A spectrum of strategies. Phytopathology, 89, 353-359 (1999).

Beuchat, L.R.: Ecological factors influencing survival and growth of human pathogens on raw fruits and vegetables. Microbes Infect., 4, 413-423 (2002).

Bhuvaneshwari, V., N. Goel and P.K. Paul: Protein- protein and DNA protein interactions mediate induction of defense genes by fruit extract of Azadirachta indica A. Juss. in Solanum lycopersicum L. Plant Cell Rep., 34, 1735-1745(2015).

Bradford, M.M.: A rapid and sensitive method for the quantitation of microgram quantities of protein utilizing the principle of protein-dye binding. Anal. Biochem., 72, 248-254 (1976).

Brandl, M.T.: Fitness of human enteric pathogens on plants and implications for food safety. Annu. Rev. Phytopathol., 44, 367-392 (2006).

Carey, C.M., M. Kostrzynska and S. Thompson: Escherichia coli 0157:H7 stress and virulence gene expression on romaine lettuce using comparative real-time PCR. J. Microbiol. Methods, 77, 235242 (2009). 
[CDC] Centers for Disease Control and Prevention (US): Ongoing multistate outbreak of Escherichia coli serotype 0157:H7 infections associated with consumption of fresh spinach-United States. Morb. Mortal. Wkly. Rep., 55, 1045-1046 (2006).

Erickson, M.C.: Internalization of fresh produce by foodborne pathogens. Annu. Rev. Food Sci. Technol., 3, 283-310 (2012).

Gaur, I., P.D. Sharma and P.K. Paul: Human pathogenic bacteria associated with field grown tomato and radish. Asian J. Microbiol. Biotechnol. Environ. Sci., 18, 753-761 (2016).

Gaur, I., P.D. Sharma and P.K. Paul: Effect of Klebsiella pneumoniae on speck disease development in Solanum lycopersicum. Indian J. Agric. Res., 51, 431-436 (2017).

Gavini, F., C. Ferragut, D. Izard, P.A. Trinel, H. Leclerc, B. Lefebvre and D.A.A. Mossel: Serratia fonticola, a new species from water. Int. J. Syst. Bacteriol., 29, 92-101 (1979).

Golberg, D., Y. Kroupitski, E. Delausov, R. Pinto and S. Sela: Salmonella typhimurium internalization is variable in leafy vegetables and fresh herbs. Int. J. Food Microbiol., 145, 250-257 (2011).

Gourion, B., M. Rossignol and J.A.A. Vorholt: Proteomic study of Methylobacterium extorquens reveals a response regulator essential for epiphytic growth. PNAS, 103, 13186-13191 (2006).

Heaton, J.C. and K. Jones: Microbial contamination of fruit and vegetables and the behavior of enteropathogens in the phyllosphere:A review. J. Appl. Microbiol., 104, 613-626 (2008).

Hedberg, C.W., F.J. Angulo, K.E. White, C.W. Langkop, W.L. Schell, M.G. Stobierski, A. Schuchat, J.M. Besser, S. Dietrich, L. Helsel, P.M. Griffin, J.W. McFarland and M.T. Osterholm: Outbreaks of salmonellosis associated with eating uncooked tomatoes: Implication for public health. Epidemiology and Infection, 122, 385-93 (1999).

Jalil, S.U. and M.I. Ansari: Plant microbiome and its functiona mechanism in response to environmental stress. Int. J. Green Pharm., 12, 81-92 (2018).

Jang, H. and K.R. Matthews: Influence of surface polysaccharides of Escherichia coli 0157:H7 on plant defense response and survival of the human enteric pathogen on Arabidopsis thaliana and lettuce (Lactuca sativa). Food Microbiology, 70, 254-261 (2018).

Klerks, M.M., E. Franz, M. van Gent-Pelzer, C. Zijlstra and A.H. van Bruggen: Differential interaction of Salmonella enterica serovars with lettuce cultivars and plant-microbe factors influencing the colonization efficiency. ISME J., 1, 620-1631.

Knief, C., N. Delmotte, S. Chaffron, M. Stark, G. Innerebner, R. Wassmann, C. von Mering and J.A. Vorholt: Metaproteogenomic analysis of microbial communities in the phyllosphere and rhizosphere of rice. ISME J., 6, 1378-1390 (2012).

Laemmli, U.K.: Cleaveage of structural proteins during the assembly of the head of Bacteriophage T4. Nature, 227, 680-685 (1970).

Lim, J.A., D.H. Lee and S. Heu: The Interaction of human enteric pathogens with plants. Plant Pathol. J., 30, 109-116 (2014).

Lindow, S.E. and M.T. Brandl: Microbiology of the phyllosphere. Appl. Environ. Microbiol., 69, 1875-83 (2003).
Martínez-Vaz, B.M., R.C. Fink, F. Diez-Gonzalez and M.J. Sadowsky: Enteric pathogen-plant interactions: Molecular connections leading to colonization and growth and implications for food safety. Microbes and Environments, 29, 123-135 (2014).

Melotto, M., S. Panchal and D. Roy: Plant innate immunity against human bacterial pathogens. Front. Microbiol., 5, 1-12 (2014).

Muller, H.E., A.G. Steigerwalt and D.J. Brenner: Isolation of Serratia fonticola from birds. Zentralbl. Bakteriol. Mikrobiol. Hyg. A., 261, 212-218 (1986).

Niemira, B.A. and P.H. Cooke: Escherichia coli 0157:H7 biofilm formation on romaine lettuce and spinach leaf surfaces reduces efficacy of irradiation and sodium hypochlorite washes. J. Food Prot., 75, 270-277 (2010).

Openwetware.org:https://openwetware.org/wiki/Cytoplasm_and_nucle ar_protein_extraction

Poza-Carrion, C., T. Suslow and S. Lindow: Resident bacteria on leaves enhance survival of immigrant cells of Salmonella enterica. Phytopathology, 103, 341-351 (2013).

Quilliam, R.S., A.P. Williams and D.L. Jones: Lettuce cultivar mediates both phyllosphere and rhizosphere activity of Escherichia coli 0157:H7. PLoS One, 7, e33842 (2012).

Sahilah, A.M., T.S. Tuan Suraya, I. Noraida, A. Ahmad Azuhairi, L.C. Chai and $R$. Son: Detection of virulence genes and enterobacterial repetitive intergenic consensus-PCR (ERIC-PCR) analysis among raw vegetables isolates of Campylobacter jejuni. Int. Food Res. J., 17, 681-690 (2010).

Schikora, A., A. Carreri, E. Charpentier and H. Hirt.: The dark side of the salad: Salmonella typhimurium overcomes the innate immune response of Arabidopsis thaliana and shows an endopathogenic lifestyle. PloS One, 3, e2279 (2008).

Schuster, M., D.J. Sexton, S.P. Diggle and E.P. Greenberg: Acylhomoserine lactone quorum sensing: From evolution to application. Annual Rev. Microbiol., 67, 43-63 (2013).

Tunnung, R., F.M. Ghazali, M.A. Noranizan, K.K. Haresh, M.B. Lesley, Y. Nakaguchi, M. Nishibuchi and R. Son: Rapid detection and enumeration of pathogenic Vibrio parahaemolyticus in raw vegetables from retail outlets. Int. Food Res. J., 18, 67-78 (2011).

Van der Linden, I., B. Cottyn, M. Uyttendaele, G. Vlaemynck, M. Maes and M. Heyndrickx: Long term survival of Escherichia coli 0157:H7 and Salmonella enterica on butterhead lettuce seeds, and their subsequent survival and growth on the seedlings. Int. J. Food Microbiol., 161, 214-219 (2013).

Vleesschauwer, D.D. and M. Hofte: Using Serratia plymuthica to control fungal pathogens of plants. CAB Reviews: Perspec. Agricul. Veteri. Sci. Nutri. Nat. Resour., 2, 1-12 (2007).

Whipps, J.M., P. Hand, D. Pink and G.D. Bending: Phyllosphere microbiology with special reference to diversity and plant genotype. J. Appl. Microbiol., 105, 1744-1755 (2008).

Zhang, Y., R. Nandakumar, S.L. Bartelt-Hunt, D.D. Snow, L. Hodges and X. Li: Quantitative proteomic analysis of the Salmonella-lettuce interaction. Microb. Biotechnol., 7, 630-637 (2014). 